\title{
Responses of Horticultural Commodities to Low Oxygen: Limits to the Expanded Use of Modified Atmosphere Packaging
}

Randolph M. Beaudry

AdDITIONAL INDEX WORDS. respiration, ripening, fermentation, glycolysis, ethanol, fruit, vegetables, safe working atmosphere

Summary. The application of low oxygen through modified atmosphere packaging (M AP) is a technique used successfully to preserve the visual quality of lettuce and some other commodities. The expansion of use of low $\mathrm{O}_{2}$ via MAP to preserve quality of most commodities is limited by technical difficulties achieving target $O_{2}$ concentrations, adverse physiological responses to low $\mathrm{O}_{2}$, and lack of beneficial responses to low $\mathrm{O}_{2}$. L ow $\mathrm{O}_{2}$ often is not used simply because the physiological responses governed by the gas are not limiting quality maintenance. For instance, shelf life may be governed by decay susceptibility, which is largely unaffected by low $\mathrm{O}_{2}$ and may actually be exacerbated by the conditions encountered in hermetically sealed packages. Physiological processes influenced by low $\mathrm{O}_{2}$ and limit storability are discussed. The interdependence of $\mathrm{O}_{2}$ concentration, $\mathrm{O}_{2}$ uptake by the product, and temperature are discussed relative to requirements for packaging films.

A

$\mathrm{n}$ important goal in some modified atmosphere packaging (M AP) systems is to generate an atmosphere sufficiently low in $\mathrm{O}_{2}$ to influence the metabolism (e.g., softening, chlorophyll degradation, tissue browning, senescence) of the product being packaged such that storability and/ or shelf life is extended. For some products, modifying both $\mathrm{O}_{2}$ and $\mathrm{CO}_{2}$ may be desirable and indeed, when the $\mathrm{O}_{2}$ partial pressure in packages is altered, so too must be that of $\mathrm{CO}_{2}$ by virtue of the system. In this presentation, however, comments will primarily be confined to the ramifications of $\mathrm{O}_{2}$ modification; a discussion of the influence of $\mathrm{CO}_{2}$ in M AP environments on metabolism is presented by Watkins (2000).

The expansion of M AP use in the future will, to some extent, require that technical and physiological limitations surrounding the application of low $\mathrm{O}_{2}$ environments be overcome. Technical challenges remain, for instance, in developing packages that maintain $\mathrm{O}_{2}$ partial pressures within tolerance levels as packages undergo changes in temperature and humidity.

D epartment of $\mathrm{H}$ orticulture, M ichigan State U niversity, M ich., East L ansing, M I 48824-1325.

The cost of publishing this paper was defrayed in part by the payment of page charges. U nder postal regulations, this paper therefore must behereby marked adverti sement solely to indicate this fact. 
Challengesalso remain in ameliorating and/ or avoiding adverse physiological responses to low $\mathrm{O}_{2}$. Also, the lack of beneficial responses of some commodities to low $\mathrm{O}_{2}$ partial pressures reduces impetusto expand use of MAP.

If low $\mathrm{O}_{2}$ is desired for packaged fruits or vegetables, knowledge of the effect of package characteristics (film type, film thickness, film area, product weight), product respiration, and environmental parameters (temperature and humidity) on the $\mathrm{O}_{2}$ partial pressure obtained in the package and the effect of this atmosphere on the quality and physiology of the enclosed product is essential. For instance, if $\mathrm{O}_{2}$ levels decline below partial pressures required to sustain aerobic respiration, then fermentation and, potentially, offflavors may result. Alternatively, if $\mathrm{O}_{2}$ levels are not low enough, then responses to these atmospheres may inad equately improvestorability. A range of nondamaging $\mathrm{O}_{2}$ (and $\mathrm{CO}_{2}$ ) levels have been published for a number of fruits and vegetables (Beaudry, 1999; Kader, 1997a; Kupferman, 1997; Richardson and Kupferman, 1997: Saltveit, 1997), minimally processed products (Gorny, 1997), and flowers and ornamentals (R eid, 1997) and are summarized (Table 1 ).

\section{Technical limitations to low $\mathrm{O}_{2}$ applic ation}

A film or package restricts gas exchange. Modified atmospheres are generated through the natural process of respiration by theenclosed product, which reduces $\mathrm{O}_{2}$ concentration and increases $\mathrm{CO}_{2}$ concentration under restricted gas exchange through the film barrier. T wo somewhat different strategies for regulating gas exchange to achieve desired gas partial pressures exist. The first strategy uses continuous films that control movement of $\mathrm{O}_{2}$ and $\mathrm{CO}_{2}$ into or out of the package. The second strategy uses perforated films with small holes or microperforationsastheprimary route of gas exchange. For both routes of gas exchange, the reduction in $\mathrm{O}_{2}$ partial pressure and increase in $\mathrm{CO}_{2}$ partial pressure create gradients that, according to Fick's Law, cause $\mathrm{O}_{2}$ to enter and $\mathrm{CO}_{2}$ to exit the package. Steadystate (constant) $\mathrm{O}$, levels are achieved in the package when the $\mathrm{O}$, uptake by the product is equal to that permeating into the package, a situation that exists only when the respiratory rate is constant (C ameron et al., 1989; J urin and Karel, 1963; T omkins, 1962). As for $\mathrm{O}_{2}$, steady-state $\mathrm{CO}_{2}$ levels in the package are achieved when $\mathrm{CO}_{2}$ production by the product equals $\mathrm{CO}_{2}$ escape from the package. This process can be augmented by adjusting the mix of gases in the package headspace at the time of package sealing.

At steady-state, $\mathrm{O}_{2}$ uptake can be depicted as follows:

$r_{\mathrm{O}_{2}}=\left(\mathrm{p}_{\mathrm{o}_{0} \mathrm{O}_{2}}-\mathrm{p}_{\mathrm{i}, \mathrm{O}_{2}}\right) \times \mathrm{P}_{\mathrm{O}_{2}} \mathrm{~A} / \mathrm{WI}$

here $\mathrm{r}_{\mathrm{O}_{2}}$ is the respiration rate $\left(\mathrm{mol} \cdot \mathrm{kg}^{-1} \cdot \mathrm{s}^{-1}\right)$ for oxygen, $\mathrm{p}_{\mathrm{i}}$ and $\mathrm{p}_{\mathrm{o}}$ are, respectively, the partial pressure in $\mathrm{kPa}(1.0 \mathrm{kPa} \approx 1 \%$ of an atmosphere) of gases outside and inside the package $\left(\mathrm{p}_{\mathrm{o}, \mathrm{O}_{2}}\right.$ is $21 \mathrm{kPa}(21 \%) \mathrm{O}_{2}$ and $\mathrm{p}_{\mathrm{i}, \mathrm{O}_{2}}$ is the steady-state $\mathrm{O}_{2}$ level in the package headspace), A is the area $\left(\mathrm{m}^{2}\right)$ of the package exposed to gas transfer, $\mathrm{W}$ is the weight $(\mathrm{kg})$ of the produce, and $\mathrm{I}$ is the thickness $(\mathrm{m})$ of the packaging film. $\mathrm{P}_{\mathrm{O}_{2}}$ isthe $\mathrm{O}_{2}$ permeability $\left(\mathrm{mol} \cdot \mathrm{m}^{-}\right.$ $\left.{ }^{1} \cdot \mathrm{m}^{-2} \cdot \mathrm{kPa}^{-1} \cdot \mathrm{s}^{-1}\right)$, respectively, for the continuous or perforated film, which increases exponentially with temperature(Beaudry et al., 1992). Thesteadystate levels of both $\mathrm{O}_{2}$ and $\mathrm{CO}_{2}$ are dependent on the interaction of respiration of the product and the permeability properties of the packaging film (Beaudry et al., 1992; C ameron, et al., 1989; Jurin and Karel, 1963). For continuous films, because the permeability of $\mathrm{CO}_{2}$ is usually 2 to 8 times higher than that of $\mathrm{O}_{2}$, the sum of $\mathrm{O}_{2}$ and $\mathrm{CO}_{2}$ concentrations is less than $20 \%$ to $21 \%$ unless the RQ is of the same magnitude (or greater) as the ratio of $\mathrm{CO}_{2}$ to $\mathrm{O}_{2}$ permeability. For perforated films, since the permeability of perforations to $\mathrm{CO}_{2}$ is only $20 \%$ lessthan to $\mathrm{O}_{2}$, the sum of $\mathrm{O}_{2}$ and $\mathrm{CO}_{2}$ concentrations is usually only slightly less than $21 \%$, the concentration of $O$ external to the package, unless the RQ is significantly greater than 1 , in which case, the sum would be larger than $21 \%$. Steady-state conditions are not always reached in packages, however, and part of the design processincludes assessing and predicting the dynamic changes in package headspace. Dynamic models have been developed to do just this (H ertog et al., 1998).

Temperature is an extremely important consideration in package design. As temperature increases, the $\mathrm{O}_{2}$ and $\mathrm{CO}_{2}$ permeability of many packaging films increases markedly. A tem- perature sensitivity factor known as the energy of activation ( $E$ a) describes the temperature sensitivity of the permeation of $\mathrm{O}_{2}$ and other gasesthrough filmsand hasunitsthat areexpressed in kiloj oules (kJ) per mole of molecules undergoing the interaction. The value of the $\mathrm{Ea}$ for $\mathrm{O}_{2}$ permeation through low density polyethylene (LDPE) is about $38 \mathrm{~kJ} \cdot \mathrm{mol}^{-1}$ (Cameron et al., 1994), which yields a 2.5 -fold (250\%) increase in permeability between 0 and $15^{\circ} \mathrm{C}$. A higher Ea would relate to a greater change in permeability over the temperature range and a lower $\mathrm{Ea}$ indicates a lower temperature responsiveness. In contrast to permeation through continuous films, the permeation of gases through perforations has an extremely low temperature sensitivity factor, being about equivalent to $4.3 \mathrm{~kJ} \cdot \mathrm{mol}^{-1}$ and so gas exchange through perforations in a package undergoes only a $10 \%$ increase with temperature in the range depicted.

The respiratory response of plant material to $\mathrm{O}_{2}$ concentration also hasa temperature sensitivity that can be mathematically described using saturation-type curves. A standard means of expressing the dependence of a reaction ( $\mathrm{O}_{2}$ uptake) on a substrate $\left(\mathrm{O}_{2}\right)$ is the $M{ }^{2}$ ichaelis-M enton model (Cameron et al., 1994; $\mathrm{H}$ ertog et al., 1998), which is primarily applied to specific enzymatic reactions, although other models have been used. The model is expressed as follows:

$r_{\mathrm{O}_{2}}=\left(V_{\text {max }} p_{\mathrm{i}_{1} \mathrm{O}_{2}}\right) /\left(\mathrm{K}_{\mathrm{m}}+\mathrm{p}_{\mathrm{i}, \mathrm{O}_{2}}\right)$

where $\mathrm{r}_{\mathrm{O}_{2}}$ is $\mathrm{O}_{2}$ uptake $\left(\mathrm{mol} \cdot \mathrm{kg}^{-1} \cdot \mathrm{s}^{-1}\right)$, $V_{\text {max }}\left(\mathrm{mol}^{\prime} \mathrm{kg}^{-1} \cdot \mathrm{s}^{-1}\right)$ is the maximal rate of ${ }^{\text {max }}$ uptake, $p_{i}$ is the partial pressure $(\mathrm{Pa})$ of $\mathrm{O}_{2}$ in the package, and $\mathrm{K}_{\mathrm{m}}$ is the $\mathrm{O}_{2}$ partial pressurein the package at $50 \%$ of $V_{\text {max. }}$. For some products, the skin and/ or flesh may offer significant resistance to gas movement, so the terms apparent $\mathrm{K}_{\mathrm{m}}$ or $\mathrm{K}_{1 / 2}$ are often substituted for $\mathrm{K}_{\mathrm{m}}$ since it includes the gradient from the interior to the exterior of the plant tissues ( $C$ ameron et al., 1994, 1995).

I mportantly, $\mathrm{V}_{\text {max }}$ can be assigned a temperature sensitivity factor in a manner similar to the process of permeation (C ameron et al., 1994). This factor can betermed the apparent $\mathrm{E}$ or $E_{a}$ app with higher values reflecting greater changes in respiration over a given temperature range. The maximal rate of respiration for most fruit and vegetable products has an Eaapp 
between 60 and $90 \mathrm{~kJ} \cdot \mathrm{mol}^{-1}$, undergoing a 4- to 6-fold increase from 0 to 15 ${ }^{\circ} \mathrm{C}$ (32 to $59^{\circ} \mathrm{F}$ ) (Beaudry et al., 1992; Cameron et al., 1994, 1995; L akakul et al., 1999). This means that product respiration increases at two or three times the rate of LDPE permeability and thirty times the rate of perforation permeability with increasing temperature. A situation where respiratory demand for $\mathrm{O}_{2}$ increasesfaster than $\mathrm{O}_{2}$ permeation presents problems with maintaining adequate $\mathrm{O}_{2}$ when the package undergoes a temperature increaseand is an example of asignificant limitation with regard to package 02 , namely, maintaining target gas levels. Theimbalancein thetemperaturesensitivity of respiration and permeation was recognized by early workers in the field (Tomkins, 1962; Workman, 1959) and later modeled (Cameron et al., 1994; $\mathrm{H}$ ertog et al., 1998).

Theoretically, there are several ways of solving the temperature problem. O ne method is to use a polymer film with a higher temperature sensitivity factor for $\mathrm{O}_{2}$ transmission. $\mathrm{H}$ igh $\mathrm{O}_{2}$ permeability, highly temperature sensitive films are now available and are being used commercially on a limited scale (Clarkeand D e M oor, 1997; Lange, 2000). A nother solution to the M AP temperature problem is to develop a package system that senses either the environment or the physiological status of the enclosed product and responds by increasing the permeability to $\mathrm{O}_{2}$ (C ameron et al., 1993). Such sense-and-respond packaging is technically difficult to develop, although some progress has been made at least conceptually (Smyth et al., 1999). A third approach to solve the MAP temperature problem is to design packages to function at the highest temperaturestypically encountered in the distribution and retail cool chain and, asfar as possible, maintain control over the temperature of the packaged product, thereby adapting to the limitationsimposed bythefilm. Thissimple solution, first suggested by Tomkins (1962) and Workman (1959), hasbeen adopted by most companies using M AP. G enerally, the lowest temperature feasible is maintained, since temperature has a much more significant influence on preserving quality than theapplication of low $\mathrm{O}_{2}$ (Kays, 1997).

The effect of temperature and other factors on package $\mathrm{O}_{2}$ can be determined or predicted using math- ematical models (Cameron et al., 1994; $\mathrm{H}$ ertog et al., 1998). The models depend on combining information that includes the effect of temperature on film permeability (Eq. 1) with information that includes the effects of temperatureand $\mathrm{O}_{2}$ on respiration (Eq. 2 ). The models permit us to predict package $\mathrm{O}_{2}$ as a function of temperature, product weight, surface area, and film thickness. By setting Eq. 1 equal to Eq. 2 and solving for the $\mathrm{O}_{2}$ partial pressure in M A packages, the following model can be developed ( $C$ ameron et al., 1994):

$\mathrm{P}_{\mathrm{i}_{\mathrm{O}}}=1 / 2\left\{\left[\left(\mathrm{~K}_{1 / 2}+\left(\mathrm{WI} / \mathrm{P}_{\mathrm{O}_{2}} \mathrm{~A}\right) \mathrm{V}_{\text {max }}-\right.\right.\right.$
$\left.\left.\mathrm{P}_{\mathrm{O}_{0}, \mathrm{O}_{2}}\right)^{2}+4 \mathrm{p}_{\mathrm{O}_{0} \mathrm{O}_{2} \mathrm{~K}_{1,2}}\right]^{1 / 2}-\left[\mathrm{K}_{1 / 2}+(\mathrm{W} \mathrm{W} /\right.$
$\left.\left.\left.\mathrm{P}_{\mathrm{O}_{2}} \mathrm{~A}\right) \mathrm{V}_{\max }-\mathrm{p}_{0, \mathrm{O}_{2}}\right]\right\}$

M odels have been published for whole apples, apple slices (L akakul et al., 1999), blueberries (Beaudry et al., 1992, C ameron et al., 1994), chicory leaves (H ertog et al., 1998), broccoli florets (Cameron et al., 1995), lettuce leaves (C ameron et al., 1995), strawberry (Joles, 1993), tomato (H ertog et al., 1998), and raspberry (Joles, 1993; J oles et al., 1994).

In addition to respiratory responses to package atmospheres, nondetrimental exposure criteria for $\mathrm{O}_{2}$ and $\mathrm{CO}_{2}$ are important pieces of information for package design and the interpretation of the package $\mathrm{O}_{2}$ models. If $\mathrm{O}_{2}$ levels get too low, fermentation results, which is linked to the development of off-flavorsand/ or tissuedamage(Kays, 1997). Thelower $\mathrm{O}_{2}$ limit for most commodities generally increases with temperature (Beaudry et al., 1992; C ameron et al., 1994, 1995; Yearsley et al., 1996).

Finally, the variation one might encounter in the respiration rate of the product and the variation in film or pore permeability should be factored into design criteria. Variation in broccoli respiration and package permeability has been measured and the effect on package $\mathrm{O}_{2}$ levels modeled (Cameron et al., 1993; Talasila et al., 1994). For any package design, there is an estimable risk of the package $\mathrm{O}_{2}$ falling below the lower $\mathrm{O}_{2}$ limit tolerated by the product, resulting in fermentation. By reducing the variability of package parameters and targeting effective, but adequate $\mathrm{O}_{2}$ concentrationswell abovethe lower $\mathrm{O}_{2}$ limit, the risk of inducing fermentation in packages can be minimized.

O nceall of the aboveinformation has been accumulated, it should be possible to design packages with a reasonably predictable performance. For instance, packages can be designed to maintain aerobic $\mathrm{O}_{2}$ levels at the highest temperature to which they will be exposed, thus avoiding fermentative conditionsatall temperatures. Alternatively, they can be designed to generatelow $\mathrm{O}_{2}$ levelsonly at high temperatures. A package $\mathrm{O}$ model such as the one specified can also be used to predict very specific package criteria. For instance, thethickness ranges that protect against fermentation can be established for specific film types (L akakul et al., 1999). It should also be noted that combination packages can be designed that use both perforation and film polymer pathways for gasexchange(Fishman et al., 1996).

Combined perforation/ permeation M AP has have features of both systemsand the attainable atmosphere combinations are in-between those of packages dependent on permeation only and those dependent on diffusion through perforations only (Beaudry, 1999; Lee, 1994). These packages would attain a sort of 'middle ground' in terms of $\mathrm{O}_{2}$ and $\mathrm{CO}_{2}$ transmission in that the temperature sensitivity for permeation and the discrimination between $\mathrm{O}_{2}$ and $\mathrm{CO}_{2}$ is somewhere between those for perforated packages and hermetic packages.

\section{Physiological limitations to low 02 application}

The application of M AP to preserve the quality of harvested plant products is limited in part by adverse and/ or nonbeneficial physiological responses to the atmospheres. Plant responses to modified $\mathrm{O}_{2}$ levels have generally been well-characterized and include responses at the levels of primary and secondary metabolism (Kader, 1997b). Of the primary metabolic responses to low $\mathrm{O}_{2}$, beneficial reactions include a reduction in respiration (i.e., $\mathrm{O}_{2}$ uptake), which can be manifested as a reduction in starch degradation and sugar consumption. Reduced respiration isoften interpreted as reflecting a reduction in global metabolism (Kays, 1997). An important negative response to low $\mathrm{O}_{2}$ is the induction of fermentation, as has been mentioned previously, and the diversion of carbon in glycolysisto acetaldehyde, ethanol, and lactate. G enerally, the lower limit of $\mathrm{O}_{2}$ content in the atmosphere is considered to be the $\mathrm{O}_{2}$ 
level at which fermentation is induced (Yearsley et al., 1996). The $O_{2}$ level at the induction point for fermentation can betermed thefermentation threshold. The fermentation threshold is not always the lower $\mathrm{O}_{2}$ limit in commercial practice, however, when benefits due to $\mathrm{O}_{2}$ levels near or below the fermentation threshold outweigh the loss in flavor or other quality parameters. This is true for fresh-cut lettuce, in particular, a situation that will be later detailed.

Of the secondary metabolic responses to low $\mathrm{O}_{2}$, important beneficial reactions include a reduction ethylenesynthesisand perception, reduced chlorophyll degradation, reduced cell wall degradation, and reduced phenolic oxidation. R educed ethylene effects can be manifested as changes in primary and secondary metabolism. The low $\mathrm{O}_{2}$-induced reduction in ethylene action likely comprises the most widely useful aspect of low $\mathrm{O}_{2}$ application and forms the basis for the controlled-atmosphere (CA) storage of climacteric fruit (Solomos, 1997). It should benoted that many of the plant responses to low $\mathrm{O}_{2}$ are altered by the presence of $\mathrm{CO}_{2}$ (Sil'va, 1998; Watkins, 2000; Yang and Chinnan, 1988).

$\mathrm{N}$ egative secondary metabolic responses to low $\mathrm{O}_{2}$ include reduced aroma biosynthesis for fruit including apple, banana, pear, peach, strawberry, and other crops ( $M$ attheisand Fellman, 2000; Shamaila et al., 1992), and the possibility of off-flavor generation (Kays, 1997). The determination as to whether a particular plant organ can be favorably affected by reduced $\mathrm{O}_{2}$ concentration depends upon the balance obtained between positive and negative responses. The following discussion details the influence of $\mathrm{O}_{2}$ on primary and secondary metabolic pathways important to fruit and vegetable quality, with emphasis on respiratory suppression.

Respiration. A reduction in the rate of respiration by the application of low $\mathrm{O}_{2}$ atmospheres has often been stated as a rationale for the use of CA and M AP. The premise has been that reducing the respiration rate reduces the rate of deterioration of the tissues, thereby extending storage life (Burton, 1974; H erner, 1997). The basis for thisargument originally stemsfrom work by Kidd and West $(1914,1927)$ on seed and fruit storage. The suggestion that reduced $\mathrm{O}_{2}$ can beapplied for the purpose of reducing respiration cannot be broadly applied, however, because, for many crops, a reduction in respiration by low $\mathrm{O}_{2}$ is accompanied by the induction of fermentation. For those commodities in which a significant reduction in respiration is possible without the induction of fermentation, the impact is often not directly on the respiratory machinery, but on ethylene action (Solomos, 1997). The following analysis of respiratory behavior servesto illustratethese points.

If one assumes that a significant reduction in respiratory (i.e., metabolic) activity is needed to add sufficient value to offset the expenses incurred in theapplication of M AP technologies to reduce $\mathrm{O}_{2}$, then there is some point at which investment in the technology is balanced by the added value. For the sake of argument, alevel of $50 \%$ reduction in respiration is suggested to be associated with sufficient enhancement of shelf life (i.e., value) such that the cost of the extra handling and materials resulting from M AP will be recovered. While this level of respiratory inhibition is arbitrary, it is coincident with the $\mathrm{K}_{1 / 2}$, a physiologically significant parameter, and serves as a benchmark for the purpose of discussion.

There are two terminal oxidases that use $\mathrm{O}_{2}$ as a substrate in this final step in respiration: cytochrome c oxidase ( $C y t O x)$ and the alternative, cyanide-insensitive, oxidase (AltO $\mathrm{x}$ ). CytO $x$ has a very high affinity for $\mathrm{O}_{2}$, having a $\mathrm{K}_{\mathrm{m}}$ of $0.1 \%$ to $0.15 \% \mathrm{O}_{2}$ in the atmosphere external to the cell, while the AltO $x$ has much lower affinity for $\mathrm{O}_{2}$, as reflected by itsK of $1 \%$ to $3 \% \mathrm{O}_{2}$ (M apson and Burton, 1962 ; Solomos, 1977a). CytO $x$ is typically present and functioning in most tissues, whereas the AltO $x$ is not always present and is commonly modulated at the molecular level or by allosteric effectors (Vanlerberghe and M cl ntosh, 1997). The simultaneous operation of both oxidases may make respiratory responses to $\mathrm{O}_{2}$ difficult to interpret. Additionally, even if only $C$ ytO $x$ were active, the external $\mathrm{O}_{2}$ level at which $\mathrm{O}_{2}$ uptake is $50 \%$ of its maximum will likely be considerably higher than $0.15 \%$ due to flesh and skin resistances to gas diffusion.

As noted previously, the $K_{1 / 2}$ includes the gradient between the interior and exterior of the plant organ and can be substantially higher than the $\mathrm{K}_{\mathrm{m}}$. The $\mathrm{K}_{1 / 2}$ for various plant parts is often in the $0.25 \%$ to $5 \% \mathrm{O}_{2}$ range and exhibits a temperature dependence, increasing with increasing temperature (C ameron et al., 1995; $\mathrm{H}$ ertog et al., 1998; Joles, 1993; Yearsley et al., 1996). The temperature dependence of the $K_{1 / 2}$ is a result of an increase in the gradient of $\mathrm{O}_{2}$ with temperature, rather than a shift in the $K_{m}$ since the $\mathrm{K}_{\mathrm{m}}$ is relatively constant within the range of physiologically relevant temperatures (Yearsley, et al., 1996). The relatively high $\mathrm{K}_{1 / 2}$ causes the curve describing the dependence of $\mathrm{O}_{2}$ uptake on $\mathrm{O}_{2}$ concentration to be rather broad for whole plant organs, especially those held at elevated temperatures, but very sharp for singlecellsand other tissues with little diffusive resistance (Fig. 1). For the remainder of the paper, discussion regarding the fermentation threshold and the $\mathrm{K}_{1 / 2}$ will pertain to $\mathrm{O}_{2}$ levels in the package atmosphere $\left(\mathrm{p}_{1, \mathrm{O}_{2}}\right)$ in that this value represents that of concern to the commercial storage operator and is the quantity most often expressed in papers on the topic of atmosphere tolerances.

It is worth mentioning that the control of $\mathrm{O}_{2}$ uptakemay not bestrictly controlled at the level of CytO $x$ and AltOx. A hypothetical system that senses the $\mathrm{O}_{2}$ concentration in plant tissues and regulates carbon flux has been suggested ( $M$ apson and Burton, 1962; Solomos, 1997b). While such a system would help explain the rather broad nature of $\mathrm{O}_{2}$-dependent curves obtained for glycolytic processes in some tissues (Silva, 1998; Solomos, 1997b), definitive proof is lacking. In some instances, skin and flesh resistances have been suggested to cause broad $\mathrm{O}_{2}$-dependent respiratorycurves (Tucker and L aties, 1985).

A convenient way to collect the respiratory data required to calculate the $K_{1 / 2}$ and the fermentation threshold involvesenclosing the desired product in packages composed of films of known permeability for a given temperature (Beaudry et al., 1992). The weight of the plant material and the thickness of the film can be varied in order to generate a range of $\mathrm{O}_{2}$ atmospheres. After some days, the $\mathrm{O}_{2}$ and $\mathrm{CO}_{2}$ levels reach steady-state at which time the rates of flux of $\mathrm{O}_{2}$ and $\mathrm{CO}_{2}$ through the package are essentially equal to their rate of uptake and pro- 


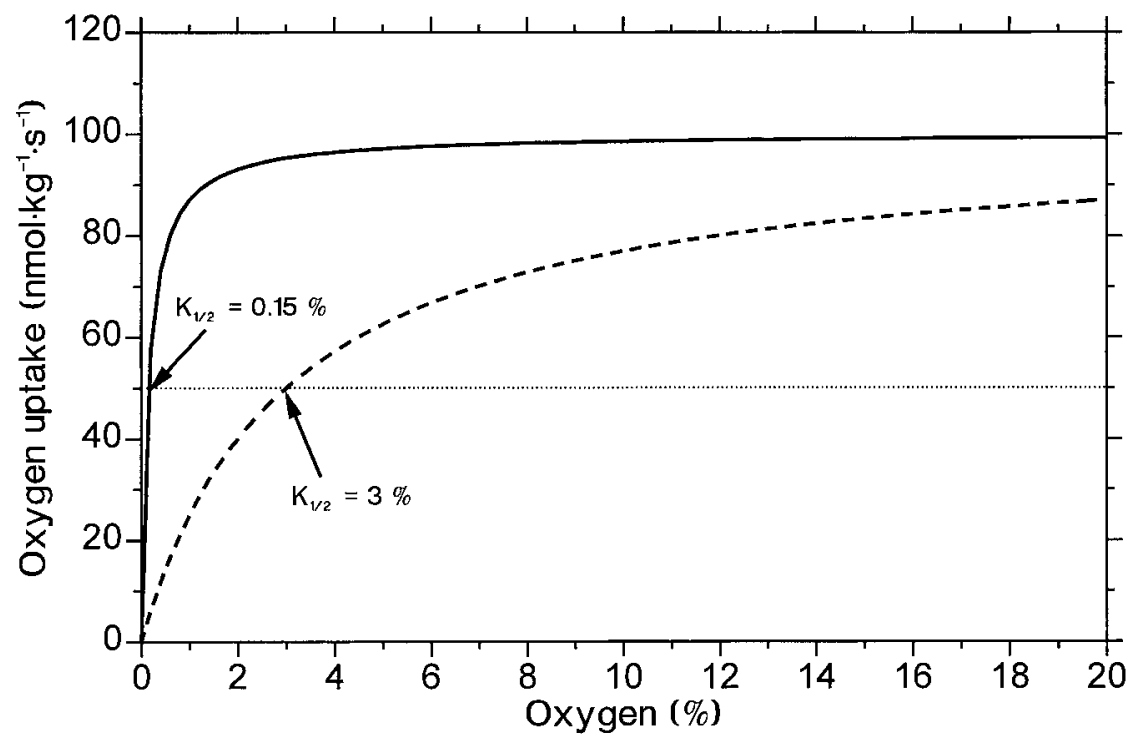

Fig. 1. H ypothetical respiratory responses to $\mathrm{O}_{2}$ for a respiratory system of low diffusive resistance exhibiting a $\mathrm{K}_{1 / 2}$ of about $0.15 \% \mathrm{O}_{2}$, representative of single cells or tissues, and a tissue with significant diffusive resistance to gas exchange with an $\mathrm{K}_{1 / 2}$ of $3 \% \mathrm{O}_{2}$.

duction, respectively. At steady-state, $\mathrm{O}_{2}$ uptake, $\mathrm{CO}_{2}$ production, and a relative indicator of fermentation, the respiratory quotient (RQ), can be determined as a function of the package $\mathrm{O}_{2}$ concentration (Fig. 2). By fitting the respiratory data with a $\mathrm{M}$ ichaelis$M$ enton equation, the $K_{1 / 2}$ can be determined. The fermentation threshold can be considered to be the $\mathrm{O}_{2}$ level below which, the RQ increases (Beaudry et al., 1992).

The difference between the $K_{1 / 2}$ for $\mathrm{O}_{2}$ uptake and the fermentation threshold can be used as a criterion for deciding whether low $\mathrm{O}_{2}$ will provide a beneficial response in terms of restricting respiration and slowing metabolism for the purpose of improving storability. If, for instance, thefermentation threshold is much lower than the apparent $K_{m}$, then a greater than $50 \%$ reduction in respiration and attendant metabolic activities can be achieved without thethreat of fermentation, thereby, in concept, safely enabling improved storability via metabolic suppression. This range of $\mathrm{O}_{2}$ levels might be termed the safe working atmosphere with respect to respiratory reduction. $0 \mathrm{n}$ the other hand, if the fermentation threshold is near or abovethe $\mathrm{K}_{1 / 2}$, it could be argued that little or no advantage due to reduced metabolic activity can be achieved by which the respiratory rate of straw-

reducing $\mathrm{O}_{2}$ since the tissueswould be compromised by fermentativeactivity. In the latter case, there would be no safe working atmosphere.

Two examples of the commoditieshaving no safeworking atmosphere include strawberry fruit and asparagus atmosphere. berry was determined using packages, the $K_{1 / 2}$ was determined to be about $1 \% \mathrm{O}_{2}$ at $20^{\circ} \mathrm{C}$, but fermentation was evident below about $1.2 \% \mathrm{O}_{2}$ (Fig. 2). Similar data are available for asparagus held at $0^{\circ} \mathrm{C}$, wherethe $\mathrm{K}_{1 / 2}$ is about $1 \%$ $\mathrm{O}_{3}$ and the fermentation threshold is $1.2 \% \mathrm{O}_{2}$ ( Silva, 1998). Based on these data, use of low $\mathrm{O}_{2}$ for the purpose of respiratory suppression would not be advisable. I $n$ fact, low $\mathrm{O}_{2}$ storage is not recommended for either of these plant materialsto extend shelf life (Table 1 ). Thisisconsistent with commercial practice in that little to no low $\mathrm{O}_{2}$ storage of either commodity occurs.

An example of a rather broad safe working atmosphere was found for apple fruit, although it was dependent upon the stage of fruit development (Fig. 3). $M$ ature, but nonripening ' $E$ mpire' apple fruit were treated with 1methylcyclopropene (1-M CP), an inhibitor of ethylene action (Serek et al., 1995; Sisler and Blankenship, 1996) to keep them in a preclimacteric stage of devel opment, or were left untreated before packaging. Packaged fruit were held at $20{ }^{\circ} \mathrm{C}$ for $14 \mathrm{~d}$. Ripening of

Fig. 2. R espiratory response to $\mathrm{O}_{2}$ and the associated $R Q$ of strawberry fruit held at $22^{\circ} \mathrm{C}\left(72^{\circ} \mathrm{F}\right)$ for $5 \mathrm{~d}$ in LDPE packages (data previously unpublished). The vertical arrow in the upper graph depicts the lower $\mathrm{O}_{2}$ limit based on the increase in fermentative activity at lower $\mathrm{O}_{2}$ concentrations. The vertical arrow in the lower graph indicates the $K_{1 / 2}$ of the fitted line. The fact that the lower $\mathrm{O}_{2}$ limit exceeds the $K_{1 / 2}$ is taken to indicate that there is no safe working 
T able 1. Oxygen $\left(\mathrm{O}_{2}\right)$ limits below which injury can occur for selected horticultural crops held at typical storage temperatures (from Beaudry, 1999; G orny, 1997; Kader, 1997a; Kupferman, 1997; R ichardson and K upferman, 1997; Saltveit, 1997). Those commodities in bold are considered to have very good to excellent potential to respond to low $\mathrm{O}_{2}$. The $\mathrm{O}_{2}$ limit does not always refer to the fermentation threshold, but may relate to discoloration or other disorder.

\section{$\mathbf{O}_{2}(\%)$}

\section{Commodity}

Broccoli (Brassica oleracea L. Group I talica)

Lettuce (chopped greenleaf, redleaf, Romaine and iceberg; Lactuca sativa L.)

M ushroom (A garicusbisporusL.)

Pear (sliced) (PyruscommunisL.)

Spinach (Spinacia oleracea L.)

Apple (sliced) (Malus $\times$ domestica Borkh.)

Apricot (Prunusarmeniaca L.)

Atemoya (A nnona squamosa $\times$ cherimola)

Avocado (Persea americana M ill.)

Banana (M usa L.)

Brussels sprouts (Brassica oleracea L. Group Gemmifera)

Broccoli (florets)

Cantaloupe (muskmelon; Cucumismelo L.)

Cherimoya (A nnona cherimola M ill.)

Cherry (sweet; Prunusavium L.)

Chicory (Cichorium intybus L.)

Cranberry (Vaccinium macrocarpon Ait.)

Cucumber (CucumissativusL.)

Grape (Vitis vinifera $L$.)

Kiwifruit (Actinidia deliciosa (A. Chev) C.F. Liang et A.R. Ferguson var. deliciosa)

Lettuce (chopped butterhead, crisphead)

Litchi (Lychee) (Litchi chinensis Sonn.)

N ectarine [Prunus persica (L.) Batsch Group]

O nion (bulb; A llium cepa L.)

Peach [Prunuspersica (L.) Batsch]

Plum (Prunus xdomestica L.)

Rambutan (N ephelium lappaceum L.)

Sweetsop (A nnona squamosa (L.))

Apple (most cultivars)

Pear (most cultivars)

Artichoke (Cynara scolymus L.)

Blackberry (R ubus L. subg. Rubus Watson)

C abbage (Brassica oleracea L. Group C apitata)

Cauliflower (Brassica oleracea L. Group Botrytis)

Carrot (shredded and cut) (D aucuscarota L.)

Celery [A pium graveolens L. dulce ( $M$ ill.) Pers.]

Corn (sweet) (Zea mays L.)

Durian (Durio zibethinus M urr.)

Fig (Ficuscarica L.)

$M$ ango (Manifera indica L.)

O live (Olea europaea L.)

Papaya (Carica papaya L.)

Pepper (green bell and chilli; Capsicum annuum L.)

Pineapple [A nanas comosus (L.) M err.]

Pomegranate (Punica granatum L.)

Raspberry ( $R$ ubusidaeus L.)

Strawberry (Fragaria xananassa D uch.)

Tomato [ Lycopersicon esculentum (L.) M ill.]

Blueberry (Vaccinium corymbosum L.)

C abbage (shredded)

Apple (some cultivars)

Cantaloupe (cubed or sliced)

Grapefruit (C itrus paradisi M acf.)

Pear (some cultivars)

Persimmon (Diospyroskhaki L.)

Potato (Solanum tuberosum L.)

M ushrooms (sliced)

Bean (green snap) (PhaseolusvulgarisL.)

Lemon (Citrusjambhiri Lush.)

Lime (Citruslimettioides Tan.)

O range [Citrussinensis(L.) O sb.]

Asparagus (A sparagus officinalis L.)

O range (sections) 


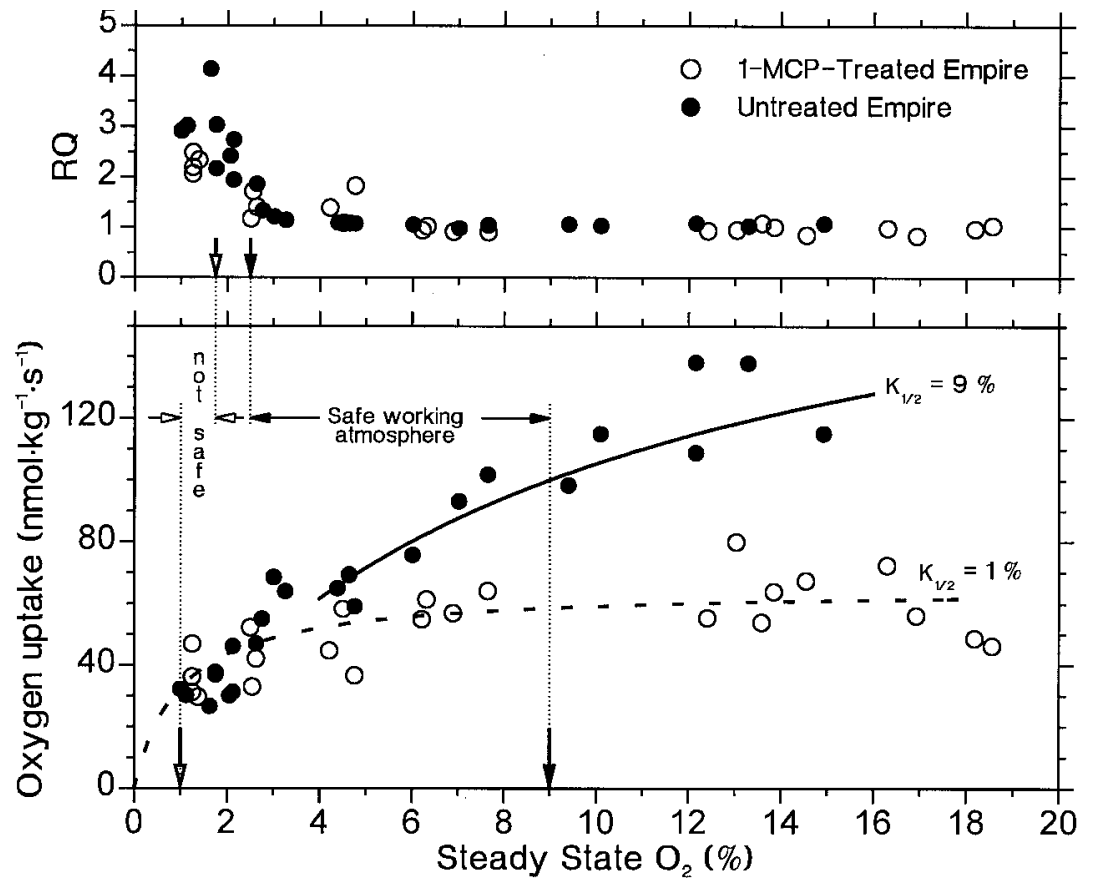

Fig. 3. R espiratory response to $\mathrm{O}_{2}$ and the associated $R Q$ of mature, unripe (1-M C P-treated) and ripening (untreated) apple fruit held at $22^{\circ} \mathrm{C}$ ( $72{ }^{\circ} \mathrm{F}$ ) for $14 \mathrm{~d}$ in LDPE packages (data previously unpublished). The vertical arrow in the upper graph depicts the lower $\mathrm{O}_{2}$ limit based on the increase in fermentative activity at lower $\mathrm{O}_{2}$ concentrations. The vertical arrow in the lower graph indicates the $K_{1 / 2}$ of the fitted line. The fact that the lower $\mathrm{O}_{2}$ limit exceeds the $K_{1 / 2}$ for unripe fruit is taken to indicate that there is no safe working atmosphere for fruit of this devel opmental stage. The fact that the $K_{1 / 2}$ exceeds the lower $O_{2}$ limit for ripening fruit is taken to indicate that there is a substantial safe working atmosphere for fruit of this developmental stage.

applefruit isinhibited by asingleexposure to 1-M CP for as long as 30 to 40 $\mathrm{d}$ at room temperature (Beaudry, unpublished data; Fan et al., 1999). U ntreated fruit ripened normally within 5 to $6 \mathrm{~d}$. The 1-MCP-treated fruit showed no outward signs of ripening throughout the study as judged by changes in green and yellow coloration or firmness loss such that the fruit were considered to bein a nonripening state. The respiratory curve for the nonripening fruit exhibited $a \mathrm{~K}_{1 / 2}$ of about $1 \% \mathrm{O}$ and a $\mathrm{Vmax}$ of about 65 $\mathrm{nmol} \cdot \mathrm{kg}^{-1} \cdot \mathrm{s}^{-1}$ (Fig. 3). The fermentation threshold wasabout $2 \% \mathrm{O}_{2}$. Thus, there was no safe working atmosphere for nonripening fruit. The implication is that for nonripening fruit, low $\mathrm{O}_{2}$ benefitsare not due to respiratory suppression, but are primarily due to effects on ethylene action, which is consistent with previousassessments (Burg and Burg, 1967; Solomos, 1997b). Ripening fruit, however, had a $\mathrm{K}_{1 / 2}$ of about $9 \% \mathrm{O}_{2}$ and a $\mathrm{V}$ max of about 200 $\mathrm{nmol} \cdot \mathrm{kg}^{-1} \cdot \mathrm{s}^{2}$. The increased respiratory rate at high $\mathrm{O}_{2}$ levels indicated that the fruit were undergoing climacteric respiratory enhancement associated with ripening. The fermentation threshold was about $2.5 \% \mathrm{O}_{2}$, yielding a safe working atmosphere of nearly $6.5 \%$ in breadth between $2.5 \%$ and $9 \%$ $\mathrm{O}_{2}$. A similar responseto $\mathrm{O}_{2}$ wasfound for 'J onathan' apple fruit, which had a safe working atmosphere of about $6 \%$ in breadth between $1 \%$ and $7 \% \mathrm{O}_{2}$ (data not shown). Insofar as the permeabilities of the apple fruit skin and flesh are not known to shift dramatically during the early stages of ripening (Park, 1990), this shift in $\mathrm{K}_{1 / 2}$ and $V$ max may reflect the induction and extensive use of the alternative oxidase as ripening commenced, an observation supported by previous research on other climacteric crops (Cruz-H ernandez and Gomez-Lim, 1995), but not yet confirmed. In any case, ripening fruit in which climacteric respiration has been induced would be expected to respond to reduced $\mathrm{O}_{2}$ levels by a reduction in $\mathrm{O}_{2}$ uptake and associated oxidative metabolism at an $\mathrm{O}_{2}$ level well above the fermentation threshold. In keeping with this expectation is the long history of successful low 0 , storage of apple fruit (Kidd and West, 1927, 1945). In the apple industry, CA storageisarelatively common practiceand typically results in a doubling or trebling of shelf life relative to refrigerated air storage (Fidler, 1965).

A similar, large safe working atmosphere is present for tomato fruit (data not shown), which respond positively to low $\mathrm{O}_{2}$ levels. U nlike apple fruit, however, there was a safe working atmosphere for both unripe, mature fruit as well as ripening fruit. The $\mathrm{K}_{1 / 2}$ increased from 3\% to $9 \% \mathrm{O}_{2}$ during ripening and the fermentation threshold remained unchanged at about $1 \% \mathrm{O}_{2}$ (data not shown). Low $\mathrm{O}_{2}$ atmo spheres significantly delay the onset of tomato ripening and slow ripening once underway (Yang and Chinnan, 1988). Despite the rather broad safe working atmosphere for tomato, advantages gained by respiratory suppression and the reduction in ethylene action by low $\mathrm{O}_{2}$ may be minimized by decay and bruising (Allen and Allen, 1950; I senburg, 1979; Saltveit, 1997). In that $\mathrm{O}_{2}$ concentrations above the fermentation threshold have little effect on the activity of most decay organisms (Brown, 1922), low $\mathrm{O}_{2}$ would not directly suppress decay. Additionally, marketing is such that extending storage life of tomato fruit for would do little to add value to the crop. Tomato production is already year-round, with no discernible breaks in fresh product availability.

Safe working atmospheres 3.5\% and $2 \% \mathrm{O}_{2}$ in width were found for broccoli and blueberries, respectively (data not shown). Broccoli respond to reduced $\mathrm{O}_{2}$ in a favorable fashion (M akhlouf et al., 1989a, 1989b; Tian et al., 1994), exhibiting a longer storage life in terms of green color retention. A benefit for low $\mathrm{O}_{2}$ on blueberries has been reported (Frisina et al., 1988), while others report little to no benefit (Ceponisand Cappellini, 1985; Smittle and M iller, 1988). Blueberry fruit are highly susceptible to decay and this feature often limits storability rather than the rate of fruit metabolism per se (Ceponis and Cappellini, 1985).

The lack of a safe working atmosphere for respiratory suppression may provide a mechanistic understanding as to why low $\mathrm{O}$, atmospheres do not extend storage life in many horticul- 
tural commodities. A clear exception appearsto bepreclimacteric applefruit, for which respiratory suppression could be damaging, but because ethylene plays a significant role in ripening and senescence, low $\mathrm{O}_{2}$ is effective in improving storability. Alternatively, the presence of a safe working atmosphere does not necessarily mean that the commodity isappropriatefor theimplementation of low $\mathrm{O}_{2}$ atmospheres. $\mathrm{L}$ argely thisisdueto factors other than respiratory (i.e., metabolic) rate that limit storability.

Ethylene. Low $\mathrm{O}_{2}$ is known to exert marked effects on ethylene biosynthesis(Abelesetal., 1992; M akhlouf et al., 1989a, 1989b). The $K_{1 / 2}$ of $1-$ aminocyclopropane carboxylic acid oxidase (ACO), the enzyme responsible for the last step in the enzymatic production of ethylene from 1aminocyclopropane carboxylic acid (ACC) has been variously reported as falling within the range of $1.4 \%$ to $10 \%$ (Abeleset al., 1992). Therequirement for $\mathrm{O}_{2}$ is dependent on the concentration of the other substrate, $A C C$, due to the fact that $A C O$ is a bisubstrate enzyme. As ACC levels increase, the $\mathrm{K}_{\mathrm{m}}$ of the enzyme for $\mathrm{O}_{2}$ declines. The mechanism is considered to be ordered bisubstratewith $\mathrm{ACO}$ first binding $\mathrm{O}_{2}$, then binding $\mathrm{ACC}$ (A beles et al., 1992).

Oxygen has also been reported to exert an effect on $\mathrm{C}_{2} \mathrm{H}_{4}$ perception (Burg and Burg, 1967) although this hasbeen disputed (A beleset al., 1992). Therefore, the effect of reduced $\mathrm{O}_{2}$ may be due to reducing ethylene sensitivity in addition to its effect on biosynthesis. The general observation for climacteric tissues, however, is that $\mathrm{O}_{2}$ concentrations that would normally not inhibit respiration in the mature green fruit still reduce the rate of ripening. For example, 'Empire' apple, fruit held in $3 \% \mathrm{O}_{2}$ and $22^{\circ} \mathrm{C}$ that were maintained in a preclimacteric, nonripening state by 1-MCP treatment exhibited little reduction in respiration (Fig. 3). H owever, apple ripening can be significantly retarded by this concentrations of $\mathrm{O}_{2}$ relative to higher $\mathrm{O}_{2}$ levels (Sfakiotakisand D illey, 1973). Thus, even if $\mathrm{O}_{2}$ does not directly impinge on ethylene perception as suggested by Abeles et al. (1992), climacteric tissue responses make it appear so. Further, for nonripening climacteric fruit, it appears that the primary function of low $\mathrm{O}_{2}$ is to sup- press ripening through ethylene action, as opposed to general metabolic suppression via respiratory inhibition.

Low $\mathrm{O}_{2}$ atmospheres have been used most commonly in commercial CA facilities to minimize ethylenedependent responses attendant to ripening of climacteric fruit, but this goal may not always be compatible with M AP for consumer packages. For instance, while the initiation of ripening can be prevented very effectively by $M A P$, it is not commonly used for this purpose since it is the ripe or nearly ripe fruit that must be packaged to permit immediateconsumption by the consumer. Ripe fruit are generally less responsive to inhibition of ethylene action than the preclimacteric fruit and moresusceptibleto handling damage and decay. The increased risks for quality loss likely do not justify the increased costs of packaging. More potential for incorporation of M AP to control ripening exists, perhaps, for lightly processed products, which require packaging anyway, or for whole fruit at the packinghouse or distributor level (Watkins et al., 1998).

Plant pigments. L ow $\mathrm{O}_{2}$ has important effects on metabolism other than those on respiration and ethylene action that can have significant impacts on quality of plant products at both the distributor and consumer level. Low $\mathrm{O}_{2}$ reduces the rate of degreening due to chlorophyll loss and inhibits browning reactions catalyzed by polyphenol oxidase (PPO). Chlorophyll loss, a desirable trait for many climacteric fruit, resultsin aquality loss for many vegetable products. Chlorophyll degradation in green vegetables can be inhibited by low $\mathrm{O}_{2}$ (M akhlouf et al., 1989a). Thisresponse is probably partly due to inhibition by $\mathrm{O}_{2}$ of ethylene-mediated promotion of senescence and perhaps by the direct action of $\mathrm{O}_{2}$ in limiting the reaction of pheophorbide a oxygenase (M atile et al., 1999). The argument for the involvement of ethylene in the degreening process is strong for broccoli. Broccoli degreening can be inhibited by low $\mathrm{O}_{2}$ ( $\mathrm{M}$ akhlouf et al., 1989a), which reduces ethylene synthesis (M akhlouf et al., 1989b) and can be enhanced by added ethylene or theethyleneanaloguepropylene(Tian et al., 1994). Further, broccoli degreening is inhibited by the specific inhibitor of ethylene action, 1-M CP (Ku and Wills, 1999; M ir and Beaudry, unpublished data).

By far, the bulk of low $\mathrm{O}_{2}$ use in consumer M A packages is for the purpose of reducing browning of the cut surfaces on lightly processed products, primarily lettuce and salad mixes. Cutting results in the mixing of cellular contents so that the various phenolic substrates such as mono-, di- and triphenols ( $\mathrm{M}$ ayer and $\mathrm{H}$ arel, 1979) come into contact with PPO, leading to the formation of high molecular weight polymers and complexes with amino acids and proteins, resulting in the formation of brown pigments. The $\mathrm{K}_{\mathrm{m}}$ for $\mathrm{O}_{2}$ in tissue browning has been variously reported as ranging from $6 \%$ to $10 \%$ (M apson and Burton, 1962; $M$ ayer and $\mathrm{H}$ arel, 1979). Smyth et al. (1998) demonstrated that $\mathrm{O}_{2}$ levels below $2 \%$ and above the fermentation threshold of about $0.5 \%$ reduced the rate of browning in lettuce. The concentration of $\mathrm{O}_{2}$ in commercial packages of lettuce and salad products is often below the fermentation threshold (Cameron et al., 1995; Peiser et al., 1997). H owever, thefermentation of lettuce, if not severe, results in very few off-flavors (Smyth et al., 1998).

Volatiles. The production of volatile esters, which contribute to characteristic aromas of a number of fruit including apple, banana, pear, peach, strawberry, and others are affected by atmosphere modification (M attheisand Fellman, 2000; Shamaila et al., 1992; Song et al., 1998). This topic will be discussed in detail ( $M$ attheis and Fellman, 2000) in these workshop proceedings. Production of aroma compounds that confer characteristic odors is generally suppressed by low $\mathrm{O}_{2}$, in part by the action of $\mathrm{O}_{2}$ on ethyleneaction in climacteric fruits, but also likely via action of $\mathrm{O}_{2}$ on oxidative processes, including respiration, required for substrate production. $M$ any volatiles that do not contribute to aromaarealso suppressed by low $\mathrm{O}_{2}$. In appleand pear, for instance, low $\mathrm{O}_{2}$ may also alter terpenoid metabolism such that the production of $\alpha$-farnesene (a semivolatile sesquiterpene that induces superficial scald) is reduced (H uelin and M urray, 1966). In general, most productsrecover from moderatelow $\mathrm{O}_{2}$ suppression of aroma volatile production and eventually develop characteristic flavors. Importantly, however, for consumer M A packages using low $\mathrm{O}_{2}$, aroma suppression immediately precedes con- 
sumption and may limit consumer acceptance.

\section{Conclusions}

The ability to modify the atmosphere surrounding plant products by sealing the plant material in permeable polymeric films hasled to the development of M AP applicationsfor bulk and consumer-sized products. M AP dates back to the middle to late 1940 s when packages were first evaluated for their capability to reduce $\mathrm{O}_{2}$ levels sufficiently to slow the ripening of apple fruit. The primary limitation of M AP application noted in the early studies was technical in nature, specifically being the lack of consistent control of $\mathrm{O}_{2}$ concentration in the package, which was a problem compounded by the lack of adequate temperature control. While temperature management has improved markedly, $\mathrm{O}_{2}$ control still remains a primary concern. Recent developments in packaging models, the advent of temperature-compensating films, and the prospects for the development of sense-and-respond packaging suggests that this limitation may eventually diminish. The physiological limitations presented by fruit and vegetable products have proven less tractable than the technological limitations mentioned, and little progress has been made in this area apart from quantifying the ability of plant material to withstand low $\mathrm{O}_{2}$ stresses and recover from low $\mathrm{O}_{2}$ exposure. Furthermore, many, if not most, plant tissues do not respond favorably to low $\mathrm{O}_{2}$ to a sufficient extent to warrant the use of MA packaging for the purpose of reducing the $\mathrm{O}_{2}$ concentration in theatmospheresurrounding the product (see also Table 1). With regard to those plant materials that do respond positively to low $\mathrm{O}_{2}$, knowledge of plant responses to $\mathrm{O}_{2}$ at the level of primary and secondary metabolism is limited. We have much to look forward to in terms of additional progress in resolving technical and physiological limitations to low $\mathrm{O}_{2}$ application to expand the use of $M^{2} A P$ in food preservation.

\section{Literature cited}

Abeles, F.B., P.W. M organ, and M .E. Saltveit, Jr. 1992. Ethylene in plant biology. 2nd ed. Academic Press, San Diego, Calif.

Allen, A.S. and N. Allen. 1950. Tomato-film findings. M odern Packaging 23:123-126, 180.
Beaudry, R.M. 1999. Effect of $\mathrm{O}_{2}$ and $\mathrm{CO}_{2}$ partial pressure on selected phenomena affecting fruit and vegetable quality. Postharvest Biol. Technol. 15:293-303.

Beaudry, R.M ., A.C. Cameron, A. Shirazi, and D.L. D ostal-L ange. 1992. M odified atmosphere packaging of blueberry fruit: Effect of temperature on package oxygen and carbon dioxide. J. Amer. Soc. H ort. Sci. 117:436-441.

Brown, W. 1922. On the germination and growth of fungi at various temperatures and in various concentrations of oxygen and carbon dioxide. Ann. Bot. 36:257-283.

Burg, S.P. and E.A. Burg. 1967. Molecular requirements for the biological activity of ethylene. Plant Physiol. 42:114-152.

Burton, WG . 1974. Somebiophysical principles underlying the controlled atmosphere storage of plant material. Ann. Appl. Biol. 78:149-168, 1974.

Cameron, A.C., R.M. Beaudry, N.H. Banks, and M .V.Yelanich. 1994. M odified-atmosphere packaging of blueberry fruit: $M$ odeling respiration and package oxygen partial pressures as a function of temperature. J. Amer. Soc. Hort. Sci. 119:534-539.

Cameron, A.C., W. Boylan-Pett, and J. Lee. 1989. D esign of modified atmosphere packaging systems: M odelling oxygen concentrations within sealed packages of tomato fruits. J. Food Sci. 54:1413-1416, 1421.

Cameron, A.C., B.D. Patterson, P.C. Talasila, and D.W. Joles. 1993. Modeling the risk in modified-atmosphere packaging: A case for sense-and-respond packaging, p. 95-102. In: M .E. Saltveit (ed.). CA'93 Proceedings. vol. 1. N RAES-71, I thaca, N.Y.

Cameron, A.C., P.C. Talasila, and D.J. Joles, 1995. Predicting the film permeability needsfor modified-atmosphere packaging of lightly processed fruitsand vegetables. $\mathrm{H}$ ortScience 30:2534.

Ceponis, M.J. and R.A. Cappellini. 1985. Reducing decay in fresh blueberries with controlled atmospheres. H ortScience 20:228-229.

Clarke, R. and C.P. D e M oor. 1997. The future in film technology: A tunable packaging system for fresh produce, p. 68-75. In: J. Gorny (ed.). CA'97 Proceedings. vol. 5. Fresh-cut fruits and vegetables and MAP. U niv. Calif. Postharvest H ort. Ser. 19.

Cruz-H ernandez, A. and M.A. Gomez-Lim. 1995. Alternative oxidase from mango is differentially regulated during fruit ripening. Planta 197:569-576.

Fan, X., S.M. Blankenship, and J.P. M attheis. 1999. 1-methylcyclopropene inhibits apple ripening. J. Amer. Soc. H ort. Sci. 124:690-695.

Fidler, J.C. 1965. Controlled atmosphere storage of apples, p. 1-7. In: Proc. Inst. Refrig., $\mathrm{N}$ atl. College for $\mathrm{H}$ eating, Ventilation, Refrig. and Fan Eng., London, England.
Fishman, S., V. Rodov, and S. Ben-Yehoshua. 1996. M athematical model for perforation effect on oxygen and water vapor dynamics in modified-atmosphere packages. J. Food Sci. 61:956-961.

Frisina, J., L Barrand, C. Cooper, C. Little, and K. Clayton-Greene. 1988. Blueberry storage trials progress report for $1987 / 1988$. H ort. Res. Inst., Knoxfield, Australia.

Gorny, J.R. 1997. A summary of CA and M A requirements and recommendations for freshcut (minimally-processed) fruits and vegetables, p. 30-66. In: J. Gorny (ed.). CA'97 Proceedings. vol. 5. Fresh-cut fruits and vegetables and M AP. U niv. Calif. Postharvest H ort. Ser. 19.

H ertog, M .L.A.T.M., H.W. Peppelenbos, R.G. Evelo, and L.M .M. Tijskens. 1998. A dynamic and generic model of gas exchange of respiring produce: the effects of oxygen, carbon dioxide and temperature. Postharvest Biol. Technol. 14:335-349.

H erner, R.C. 1987. H igh CO effects on plant organs, p. 239-253. In: J. Weichman (ed.). Postharvest physiology of vegetables. M arcel D ekker, Inc., N ew York.

Huelin, F.E. and K.E. Murray. 1966. a Farnesene in the natural coating of apples. $\mathrm{Na}$ ture (London) 210:1260-1261.

I senberg, F.M .R. 1979. Controlled atmosphere storage of vegetables. H ort. Rev. 1:337-394.

Joles, D.W. 1993. M odified-atmosphere packaging of raspberry and strawberry fruit: $C$ haracterizing the respiratory response to reduced $\mathrm{O}_{2}$, elevated $\mathrm{CO}_{2}$ and changes in temperature. MS thesis. M ich. State U niv., E. Lansing.

Joles, D.W., A.C. Cameron, A. Shirazi, P.D. Petracek, and R.M. Beaudry. 1994. M odifiedatmosphere packaging of ' $\mathrm{H}$ eritage' red raspberry fruit: Respiratory response to reduced oxygen, enhanced carbon dioxide, and temperature. J . Amer. Soc. H ort. Sci. 119:540-545.

J urin, V. and M. Karel. 1963. Studieson control of respiration of $\mathrm{M} \mathrm{Cl}$ ntosh apples by packaging methods. Food Technol. 17:104-108.

Kader, A.A. 1997a. A summary of CA requirements and recommendations for fruits other than apples and pears, p. 1-36. In: A. Kader (ed.). CA'97 Proceedings. vol. 2. Fruits other than apples and pears. U niv. Calif. Postharvest H ort. Ser. 17.

Kader, A.A. 1997b. Biological bases of $\mathrm{O}_{2}$ and $\mathrm{CO}_{2}$ effects on postharvest life of horticultural perishables, p. 160-163. In: M.E. Saltveit (ed.). CA'97 Proceedings. vol. 4. Vegetables and ornamentals. U niv. Calif. Postharvest $\mathrm{H}$ ort. Ser. 18.

Kays, S.J . 1997. Postharvest physiology of perishable plant products. Van N ostrand Reinhold, N.Y.

Kidd, F. and C. West. 1914. The controlling influence of carbon dioxide in the maturation, 
dormancy and germination of seeds. Proc. Royal Soc. London, B 87:408-421.

Kidd, F. and C. West. 1927. A relation between the concentration of oxygen and carbon dioxide in the atmosphere, rate of respiration, and length of storage of apples. Food Invest. Board Rep. London for 1925, p. 41-42.

Kidd, F. and C. West. 1945. Respiratory activity and duration of life of apples gathered at different stages of development and subsequently maintained at constant temperature. Plant Physiol. 20:467-504.

Ku, V.V.V. and R.B.H. Wills. 1999. Effect of 1methylcyclopropene on the storage life of broccoli. Postharvest Biol. Technol. 17:127-132.

Kupferman, E. 1997. Controlled atmosphere storage of apples, p. 1-30. In: E.J. M itcham (ed.). CA'97 Proceedings. vol. 3. Apples and Pears. U niv. Calif. Postharvest H ort. Ser. 16.

Lakakul, R., R.M . Beaudry, and R.J . H ernandez. 1999. Modeling respiration of apple slices in modified-atmosphere packages. J. Food Sci. 64:105-110.

Lange, D.L. 2000. N ew film technologies for horticultural products. HortT echnology 10(3):487-490.

Lee, L.J. 1994. Analysis, design, evaluation and modelling of bulk packaging systems under optimal modified atmosphere for storage and transportation of fruits and vegetables. PhD diss. Laval U niv., Q uebec, Canada.

M akhlouf, J., C. Willemot, J. A rul, F. C astaigne, and J.-P. Emond. 1989a. Long-term storage of broccoli under controlled atmosphere. HortScience 24:637-639.

M akhlouf, J., C. Willemot, J. A rul, F. C astaigne, and J.-P. Emond. 1989b. Regulation of ethylene biosynthesis in broccoli flower buds in controlled atmospheres. J. Amer. Soc. H ort. Sci. 114:955-958.

M apson, L.W., and W.G. Burton. 1962. The terminal oxidases of potato tuber. Biochem. J. 82:19-25.

$M$ atile, $P$., S. H örtensteiner, and $H$. Thomas. 1999. Chlorophyll degradation. Annu. Rev. Plant Physiol. 50:67-95.

M attheis, J.P. and J.K. Fellman. 2000. I mpacts of modified atmosphere packaging and controlled atmospheres on aroma, flavor and quality of horticultural commodities. H ortT echnology 10(3):507-510.

M ayer, A.M . and E. H arel. 1979. Polyphenol oxidasesin plants. Phytochemistry 18:193-215.

Park, Y.M . 1990. G as exchange in apples: pathways for gas exchange, changes in resistance to gas diffusion during fruit development and storage, and factors affecting the changes. PhD diss. Cornell U niv., I thaca, N.Y.
Peiser, G., G. López-Gálvez, and M . Cantwell. 1997. Changes in off-odor volatiles of salad products during storage, p. 23-28. In: J. G orny (ed.). CA'97 Proceedings. vol. 5. Fresh-cut fruits and vegetables and MAP. U niv. Calif. Postharvest H ort. Ser. 19.

Reid, M.S. 1997. A summary of CA and M A requirements and recommendations for ornamentals and cut flowers, p. 129-136. In: M.E. Saltveit (ed.). CA'97 Proceedings. vol. 4. Vegetables and ornamentals. U niv. Calif. Postharvest $\mathrm{H}$ ort. Ser. 18.

Richardson, D.G. and E. Kupferman. 1997. Controlled atmosphere storage of pears, p. 3135. In: E.J. M itcham (ed.). CA'97 Proceedings. vol. 2. Applesand pears. U niv. Calif. Postharvest $\mathrm{H}$ ort. Ser. 16

Saltveit, M .E. 1997. A summary of CA and M A recommendations for harvested vegetables, $p$. 98-117. In: M.E. Saltveit (ed.). CA'97 Proceedings. vol. 4. Vegetables and ornamentals. U niv. Calif. Postharvest H ort. Ser. 18.

Serek, M , E.C. Sisler, and M.S. Reid. 1995. 1$M$ ethylcyclopropene, a novel gaseous inhibitor of ethylene action, improves the life of fruits, cut flowers and potted plants. Acta H ort. 394:337345.

Sfakiotakis, E.M . and D.R. D illey. 1973. Induction of autocatalytic ethylene production in apple fruits by propylene in relation to maturity and oxygen. J. Amer. Soc. H ort. Sci. 98:504508.

Shamaila, M., W.D. Powire, and B.J. Skura. 1992. Analysis of compounds from strawberry fruit stored under modified atmosphere packaging (M AP). J. Food Sci. 5:1173-1176.

Silva, S. 1998. Regulation of glycolytic metabolism in asparagus spears (A sparagus officinalis L.), PhD thesis. M ich. State U niv., E. L ansing.

Sisler, E. and S. Blankenship. 1996. Patent N o. $5,518,988$. M ethod of counteracting an ethylene response in plants. $21 \mathrm{M}$ ay 1996.

Smittle, D.A. and W.R. M iller. 1988. Rabbiteye blueberry storage life and fruit quality in controlled atmospheres and air storage. J. Amer. Soc. H ort. Sci. 113:723-728.

Smyth, A.B., J. Song, and A.C . C ameron. 1998. $M$ odified atmosphere packaged cut iceberg lettuce: Effect of temperature and $\mathrm{O}_{2}$ partial pressure on respiration and quality. J. Agr. Food Chem. 46:4556-4562.

Smyth, A.B., P.C. Talasila, and A.C. Cameron. 1999. An ethanol biosensor can detect lowoxygen injury in modified atmosphere packages of fresh-cut produce. Postharvest Biol. T echnol. 15:127-134.

Solomos, T. 1977a. Cyanide-resistant respiration in higher plants. Ann. Rev. Plant Physiol. 28:279-97.
Solomos, T. 1997b. Effects of hypoxia on the senescence of horticultural crops, p. 138-148. In: M.E. Saltveit (ed.). CA'97 Proceedings. vol. 4. Vegetables and ornamentals. U niv. Calif. Postharvest H ort. Ser. 18.

Song, J., W. D eng, L. Fan, J. Verschoor, and R. Beaudry. 1998. Aroma volatiles and quality changes in modified atmosphere packaging, $\mathrm{p}$. 85-95. In: J.R. Gorny (ed.). CA'97 Proceedings. vol. 4. Vegetables and ornamentals. U niv. Calif. Postharvest H ort. Ser. 18.

Smyth, A.B., J. Song, and A.C. Cameron. 1998. $M$ odified-atmosphere packaged cut iceberg lettuce: effect of temperature and 02 partial pressure on respiration and quality. J. Agr. Food Chem. 46:4556-4562.

Talasila, P.C., A.C. Cameron, and D.W. Joles. 1994. Frequency distribution of steady-state oxygen partial pressuresin modified-atmosphere packages of cut broccoli. J. Amer. Soc. H ort. Sci. 119:556-562.

Tian, M.S., C.G. Downs, R.E. Lill, and G.A. King. 1994. A role for ethylene in the yellowing of broccoli after harvest. J. Amer. Soc. H ort. Sci. 119:276-281.

Tomkins, R.G. 1962. Film packaging of fresh fruit and vegetables-The influence of permeability. Inst. Packaging Conf. Guide 1961, L arkfield, M aidstone, Kent, England. p. 64-69.

Tucker, M . and G. Laties. 1985. The dual role of oxygen in avocado respiration: Kinetic analysis and computer modeling of diffusion-affected respiratory oxygen isotherm. Plant Cell Environ. 9:117-127.

Vanlerberghe, G.C. and L. M clntosh. 1997. Alternative oxidase: from geneto function. Annu. Rev. Plant Physiol. 48:703-34.

Watkins, C.B. 2000. Responses of horticultural commodities to high carbon dioxide as related to modified atmosphere packaging. $\mathrm{H}$ ortT echnology 10(3):501-506.

Watkins, C.B., P.L. Brookfield, H .J . Elgar, and S.P. M CL eod. 1998. D evelopment of a modified atmosphere package for export of apple fruit, p. 586-592. In: S. Ben-Yehoshua (ed.). Proc. 1997 Intl. Congr. Plastics Agr. Laser Pages Publ. Ltd., J erusalem, I srael.

Workman, M . 1959. The status of polyethylene film liners to provide modified atmosphere for the storage of apples. Eastern Fruit Grower 23:6,10-14.

Yang, C.C. and M .S. Chinnan. 1988. M odeling the effect of $\mathrm{O}_{2}$ and $\mathrm{CO}_{2}$ on respiration and quality of stored tomatoes. Trans. Amer. Soc. Agr. Eng. 31:920-925.

Yearsley, C.W., N.H. Banks, S. Ganesh, and D.J. Cleland. 1996. Determination of lower oxygen limits for apple fruit. Postharvest Biol. Technol. 8(2):95-109. 